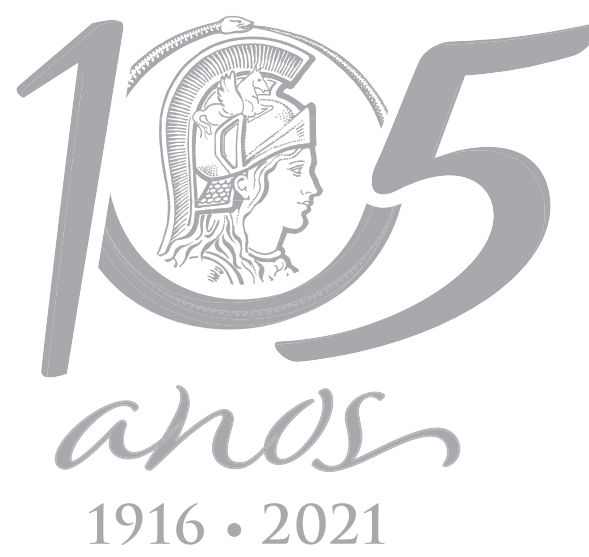

\title{
ECOSYSTEMS
}

\section{Fitness and mating compatibility of Chrysodeixis includens (W.) (Lepidoptera: Noctuidae) populations collected in different provinces and crops in Argentina}

\author{
LUCIANA C. DAMI, MARÍA INÉS HERRERO, AUGUSTO S. CASMUZ, RAÚL A. \\ ALZOGARAY \& GERARDO A. GASTAMINZA
}

\begin{abstract}
Chrysodeixis includens, is an important Plusiinae pest that feeds on soybean, beans, and cotton. This species has a genetic structure determined by molecular markers in populations collected in soybean crops in Brazil and has developed resistance to insecticides. This had led to an increased interest in the genetic diversity of its populations in Argentina. This study aimed to characterize the fitness parameters and mating compatibility of geographically distant C. includens populations and on different host plants in Argentina. Intra- and inter-population crosses revealed that $C$. includens populations from Tucumán and Santiago del Estero provinces did not present any evidence of prezygotic and postzygotic incompatibilities, suggesting that both populations collected from soybean plants belonged to a single wideranging species. Prezygotic and postzygotic incompatibilities were detected between populations collected from different crops (soybean and bean). These incompatibilities may be caused by the different nutrients that each plant species renders, or the specific pest control strategies which may affect $C$. includens behavior. Studies of the genetic structure of $C$. includens populations based on mating isolation on other crops, as well as of the impact of management strategies on the specie, will increase understanding of the reproductive compatibility revealed by the present study.
\end{abstract}

Key words: Bean, fitness, mating compatibility, northern Argentina, soybean, soybean looper.

\section{INTRODUCTION}

The soybean looper Chrysodeixis includens Walker1857(Lepidoptera: Noctuidae), is a Plusiine pest that feeds of numerous crops plants of great economic value (Specht et al. 2015). Its origin is unclear, but it is recognized as a migratory species restricted to the Western hemisphere, from The United States of America (USA) in the north to southern South America (Navarro et al. 2009, Barrionuevo et al. 2012). Chrysodeixis includens is a polyphagous species that attacks beans (Phaseolus vulgaris L.), cotton (Gossypium hirsutum L.), tobacco (Nicotiana tabacum L.), flax (Linum usitatissimum L.), sunflower (Helianthus annuus L.), alfalfa (Medicago sativa L.), and horticultural crops, among others (Navarro et al. 2009, Barrionuevo et al. 2012, Specht et al. 2015), but it shows preference for legumes, such as soybean (Glycine max L.). The period of greatest leaf consumption of $C$. includens in soybean, takes place after growth stage R3, which is a critical phase that directly impact on yield (Carter-Wientjes et al. 2004, Casmuz et al. 2015). In The USA, C. includens is the most destructive defoliation pest that attacks the soybean crop 
(Moonga \& Davis 2016). In Brazil, it has also become an important phytosanitary problem in soybean and cotton production since early 2000's (Moscardi et al. 2012, De Lima Viana et al. 2014, Yano et al. 2015), and their populations have been considered to be of growing importance for bean, due to the damage caused in this crop (Baldin et al. 2014).

Chrysodeixis includens is an important pest in Argentina from $33^{\circ}$ south latitude northwards being present in the northwest and the northeast regions, Córdoba and Buenos Aires provinces (Navarro et al. 2009, Barrionuevo \& San Blas 2015). In the 2013/2014 growing season, in soybean field of San Agustín (Tucumán province, Argentina) this species caused a $20.2 \%$ defoliation and a $19.7 \%$ yield reduction (Casmuz et al. 2014). In the last season 2017/2018 farmers of Rosario de la Frontera county (Salta province, Argentina), recorded outbreaks of this pest in bean crops above the level of the economic damage and have had to resort to three agrochemical sprays to their control. Currently, insecticides and genetically modified soybean and cotton that express the insecticidal protein Cry1Ac of Bacillus thuringiensis are used in Argentina to control C. includens. In The USA, resistance to insecticides (organophosphates, carbamates and pyrethroids) and control failures with IGR (insect growth regulator) insecticides (methoxyfenozide) (Owen et al. 2013) have been reported for C. includens (Felland et al. 1990, Higley \& Boethel 1994, Mascarenhas \& Boethel 2000). Casmuz et al. (2014) also indicated that the mixture of pyrethroid insecticides with organophosphates had no control over $C$. includens in soybean in Tucumán (Argentina). Moreover, Mascarenhas et al. (1998) found that C. includens field-collected larvae from U.S. had a lower susceptibility to the Bacillus thuringiensis variety kurstaki insecticide as compared to a reference laboratory population.
Additionally, some insect populations identified as the same species may yet display different biological and genetic traits and show reproductive isolation (cryptic species), preventing complete gene flow among populations as consequence of the presence of prezygotic and postzygotic barriers (Drès \& Mallet 2002, Bickford et al. 2007). Therefore, identifying cryptic species is important not only to explain the evolution of phytophagous insects, but also to understand the effect of susceptibility of pest populations to different control tactics (Pérez Contreras 1999, Rull et al. 2012, Joyce et al. 2014). It has led to an increased interest in fully understanding $C$. includens genetic diversity and gene flow between geographically distant populations of $\mathrm{C}$. includens, and between populations collecting in different crops. Palma et al. (2015) carried out the first molecular characterization of $\mathrm{C}$. includens populations in soybean crops from Brazil with molecular markers of the Inter Simple Sequence Repeat (ISSR) type, determining the existence of genetic structuring in populations which was not related to geographical distances. Also, structured genetic populations have been reported for other Plusiinae species, the cabbage looper Trichoplusia ni Hübner 1800-1803 (Lepidoptera: Noctuidae) (Zhu et al. 1997, Evenden et al. 2002, Franklin et al. 2010). These studies revealed variation in their pheromone composition and the presence of haplotypes.

The objective of this study was to characterize biological, reproductive parameters, and mating compatibility of $\mathrm{C}$. includens populations collected in different host plant and geographical distance in Argentina, to determine whether this pest comprises a complex of cryptic species, or simply consist of a single wide-ranging species.

Thus, $C$. includens specimens were collected from soybean crops in Tucumán and Santiago del Estero provinces, to establish the influence 
of geographic distance and from bean crop in Salta province, to establish the influence of host plant association on reproductive isolation. This research provides information about reproductive compatibility of soybean loopers, which has remained undocumented until now. This information will be useful for understanding reproductive compatibility among $C$. includens populations, which is necessary for designing sustainable strategies to control this species in Argentina.

\section{MATERIALS AND METHODS}

\section{Insect sampling}

Soybean looper larvae were collected during March and April 2016 in the northern Argentina. Larvae were collected from soybean crops in Tucumán (7 de Abril, 26²0' 27.99" S, 64 30' 47.46" W) and Santiago del Estero provinces (Sacháyoj, 26 41' 23.63" S, 61 49' 41.23" W). In Salta province, larvae were collected from bean crops (Rosario de la Frontera, 25 56' 53.91" S, $\left.65^{\circ} 6^{\prime} 57.63^{\prime \prime} \mathrm{W}\right)$. The three sampling points are located within the Chacoan Province Region, according to the Biogeographical regionalization of the Neotropical region proposed by Morrone (2014).

At each sampling site, a minimum of 300 larvae (instars 3-6) were collected using a vertical cloth as described by Drees \& Rice (1985). Each larva was placed in a plastic tube (12 $\mathrm{cm}$ tall and with a $1.5 \mathrm{~cm}$ diameter) containing one soybean or bean leaf. The larvae were taken to the laboratory and kept in breeding chambers under controlled conditions (at $27 \pm 2$ oC, 70$75 \%$ relative humidity and 14:10 h light:dark photoperiod). All larvae were examined following procedures described by Barrionuevo \& San Blas (2015) to confirm the species. After the emergence of adults a voucher specimens from each population were deposited in the insect collection of Sección Zoología Agrícola, at Estación Experimental Agroindustrial Obispo Colombres (EEAOC) (Tucumán, Argentina).

\section{Insect rearing}

Approximately 180 adults (90 females and 90 males) were randomly selected among the larvae collected, and reared to establish an experimental colony for each population. Approximately 30 female and 30 males were placed in cylindrical oviposition cages $(40 \mathrm{~cm}$ tall and with a $20 \mathrm{~cm}$ diameter), lined with polyethylene bags. For aeration, both ends of the cage were covered with a nylon cloth. The cages were placed on plastic trays lined with moistened polyurethane foam. Each population was maintained in the same chamber under identically controlled conditions (at $27 \pm 2$ 으, 70 - 75\% relative humidity and a 14:10 h light:dark photoperiod). Food was provided via a cotton plug saturated with a mixture of honey and water (1:1), which was replaced every day. Cages were checked daily for oviposition and adult mortality. Eggs were collected daily from the cages and placed in $1000 \mathrm{ml}$ plastic containers lined with moistened filter paper. Once they had emerged, neonate larvae were placed individually in glass tubes and fed on an artificial larval diet that included bean flour (Grandiet ${ }^{\circledR}$, Buenos Aires, Argentina), wheat germ (Grandiet ${ }^{\circledR}$, Buenos Aires, Argentina), brewer's yeast (Calsa ${ }^{\circledR}$, Tucumán, Argentina), vitamin $C$ (Anedra ${ }^{\circledR}$, Buenos Aires, Argentina), sorbic acid (Anedra ${ }^{\circledR}$, Buenos Aires, Argentina), sodium benzoate (Todo Droga ${ }^{\circledR}$, Córdoba, Argentina), vitamin supplement amino acids (Ruminal ${ }^{\circledR}$, Buenos Aires, Argentina), and methylparaben (Todo Droga ${ }^{\circledR}$, Córdoba, Argentina) (Murúa et al. 2003). Artificial diet was replaced every 2-3 days. As larvae pupated, pupae were sexed and placed in cup containers with filter paper, until adults emerged. Adults were used to initiate a new generation. After 
establishing a colony for each population, F1 generation of field-collected strains was used for the fitness study, and F2 generation was used to begin the parental crosses in the mating compatibility study. The following generations for the mating compatibility studies (F3-F5) were originated from the parental crosses.

\section{Fitness of soybean looper populations}

From each experimental C. includens colony, 200 eggs were randomly selected to analyze the following parameters: adult sex ratio, duration of egg, instars larval and pupal stages, and pupal mass (obtained $24 \mathrm{~h}$ after pupation). Adult sex ratio was determined in pupal stage according to the Angulo \& Weigert's methodology (1985).

Among the adults obtained, couples (females and males) were randomly selected to determine reproductive parameters. One virgin female and one virgin male (24 hours old) were selected from each population and placed in cylindrical oviposition cages, similar to those described above $(40 \mathrm{~cm}$ tall and with a $20 \mathrm{~cm}$ diameter).

Dead females were dissected to establish the presence and number of spermatophores present in their reproductive tract, to determine whether mating had occurred. Duration of preoviposition, oviposition, and post-oviposition periods, fecundity (number of eggs deposited by a female during her entire life period), fertility (percentage of hatched eggs) and adult longevity were recorded.

\section{Reproductive compatibility between soybean looper populations}

Two crossing experiments were performed to determine rep roductive compatibility between $C$. includens populations: 1) between populations distant geographically and collected from soybean crop (Tucumán and Santiago del Estero provinces); and 2) between populations collected from different host plants (soybean and bean crops from Tucumán and Salta provinces, respectively).

The crossings were performed following the methodologies described by Herrero et al. (2017). To determine compatibility, one virgin female and one virgin male (both being 24 hours old) were used. Four different types of crosses were performed: i) parental crosses using parents from the same population (in this case, single pair mating from the fitness studies were used); ii) hybrid crosses using one parent from different populations; iii) backcrosses, some with the female progenitor as the recurrent parent, and others with the male progenitor as the recurrent parent; and iv) interhybrid mating crosses between F1 hybrids from different populations. A subset of larval progeny (F1) from each fertile cross was monitored for survival until pupation, and then reared to adulthood. The parameters measured to determine compatibility were as follows: presence and number ofspermatophores per female, preoviposition, oviposition and postoviposition period duration, total fecundity, and total fertility.

\section{Data analysis}

Fitness data from different populations were compared by Kruskal-Wallis (1952) test $(P>0.05)$, because they did not show normal distribution. For the reproductive compatibility studies, due to the high number of combinations, the performance of all parental crosses was compared with that deriving from other types of crosses (hybrid crosses, backcrosses, and interhybrid mating), using Kruskal-Wallis (1952) test $(P>0.05)$. For all of these studies, the data of duration of preoviposition, oviposition and postoviposition periods were compared in the case of females that had laid eggs, whereas fecundity values were compared considering all females, including those that had not laid 
eggs. For fertility, females that had laid eggs but had no spermatophores were not included. For the number of spermatophores, females that had none in their tract were included as a value representing copula failure in all cross types. All data were analyzed using InfoStat 2016 software (Di Rienzo et al. 2008).

\section{RESULTS}

All adults from the three sampled populations were identified as $C$. includens based on the morphology of their larvae (Barrionuevo \& San Blas 2015).

\section{Fitness of $C$. includens populations}

In total, 135, 137 and 124 individuals from Tucumán, Salta and Santiago del Estero populations, respectively, were used in this study. The life stage and reproductive parameters are presented in Table I. Significant differences were detected in the duration of the L1, L2, L3, L5 and L6 instars larval, duration of overall larval stage and pupal stages. The duration of L1, L2 and L6 instars larval from Salta population collected in bean crop (4.04, 3.05 and 5.55 days, respectively) were significantly longer than those from Tucumán (2.86, 2.37 and 4.06 days, respectively) and Santiago del Estero (2.19, 2.35 and 4.31 days, respectively) populations collected in soybean crop (L1: $H=251.61, P=<0.0001 ; L 2: H=82.99, P=$ $<0.0001$ and $L 6: H=92.89, P=<0.0001)$. However, the duration of L3 instar larval from Salta population (1.32 days) was significantly low than others populations of Tucumán and Santiago del Estero (1.94 and 2.04 days, respectively) $(H=85.70, P=<0.0001)$. The $L 5$ instar larval from Tucumán and Salta populations (3.14 and 2.84 days, respectively) were significantly longer than from Santiago del Estero population (2.67 days) $(H=7.55, P=0.0134)$. The duration of overall larval stage from Salta population collected in bean crop (18.38 days), was significantly longer than others population collected from soybean crop (14.7 days for both populations) ( $H=208.22$, $P=<0.0001)$. Duration of the pupal stage from Santiago del Estero and Salta populations (8.6 days for both) was significantly longer than from Tucumán populations (7.78 days) $(H=59.90, P=$ $<0.0001)$. The duration of the preoviposition period from Santiago del Estero population (5.13 days) was significantly longer than from Salta and Tucumán populations, in decreasing order (4.58 and 3.25 days, respectively) $(H=9.39, P=$ 0.0074). No significant differences were detected between the remaining fitness and reproductive parameters (Table I).

\section{Reproductive compatibility between $C$. includens populations distant geographically and collected from the same crop}

In total, 43 parental crosses, 43 hybrid crosses, 153 backcrosses and 63 interhybrid matings were made between Tucumán and Santiago del Estero populations (Table II). Significant differences were found in the duration of preoviposition $(\mathrm{H}=$ 9.07, $P=0.0225)$, and postoviposition periods $(H=$ $7.91, P=0.0407)$, fecundity $(H=20.58, P=0.0001)$ and fertility rates $(H=18.83, P=0.0003)$ (Tables II and IV). The results obtained in the four types of crosses, show a successful matings between Tucumán and Santiago del Estero populations.

\section{Reproductive compatibility between $C$. includens populations collected from different crops}

In total, 37 parental crosses and 60 hybrid crosses were made between Tucumán and Salta populations collected in soybean and bean crops, respectively (Table III). Significant differences were found in preoviposition period duration $(H=5.84, P=0.0141)$, fecundity $(H=8.27$, $P=0.0033)$ and fertility rates $(H=12.22, P=0.0003)$, 
Table I. Biological and reproductive parameters of Chrysodeixis includens populations, collected in Tucumán, Santiago del Estero and Salta provinces in Argentina.

\begin{tabular}{|c|c|c|c|c|c|c|c|c|c|}
\hline Life cycle stages & $\begin{array}{l}\text { Tucumán } \\
\text { population } \\
\text { (soybean) }\end{array}$ & $\mathbf{N}$ & Range & $\begin{array}{c}\text { Santiago } \\
\text { del Estero } \\
\text { population } \\
\text { (soybean) }\end{array}$ & $\mathbf{N}$ & Range & $\begin{array}{c}\text { Salta } \\
\text { population } \\
\text { (bean) }\end{array}$ & $\mathbf{N}$ & Range \\
\hline Egg & $4,19 \pm 0,05 a$ & 135 & $3-6$ & $4,09 \pm 0,06 a$ & 124 & $3-5$ & $4,12 \pm 0,05 a$ & 137 & $3-5$ \\
\hline L1 & $2,86 \pm 0,05 b$ & 135 & $2-5$ & $2,19 \pm 0,04 a$ & 124 & $2-4$ & $4,04 \pm 0,05 c$ & 135 & $3-8$ \\
\hline L2 & $2,37 \pm 0,06 a$ & 131 & $1-5$ & $2,35 \pm 0,05 a$ & 122 & $2-4$ & $3,05 \pm 0,05 b$ & 131 & $2-5$ \\
\hline L3 & $1,94 \pm 0,05 b$ & 126 & $1-4$ & $2,04 \pm 0,05 b$ & 122 & $1-9$ & $1,32 \pm 0,06 a$ & 128 & $1-4$ \\
\hline L4 & $2,13 \pm 0,06 a$ & 126 & $1-5$ & $2,13 \pm 0,05 a$ & 119 & $1-4$ & $2,23 \pm 0,06 a$ & 128 & $1-5$ \\
\hline L5 & $3,14 \pm 0,15 b$ & 126 & $1-10$ & $2,67 \pm 0,15 a$ & 119 & $1-15$ & $2,84 \pm 0,13 b$ & 127 & $1-14$ \\
\hline L6 & $4,06 \pm 0,11 a$ & 71 & $2-7$ & $4,31 \pm 0,11 a$ & 90 & $3-9$ & $5,55 \pm 0,09 b$ & 114 & $3-13$ \\
\hline $\begin{array}{l}\text { Overall larval } \\
\text { stage }\end{array}$ & $14,75 \pm 0,13 a$ & 126 & $11-22$ & $14,72 \pm 0,13 a$ & 118 & $12-22$ & $18,38 \pm 0,15 b$ & 124 & $16-28$ \\
\hline Pupa & $7,78 \pm 0,08 a$ & 122 & $6-10$ & $8,65 \pm 0,07 b$ & 114 & $7-10$ & $8,61 \pm 0,08 b$ & 105 & $7-11$ \\
\hline Pupal mass & $0,25 \pm 0,003 a$ & 122 & $\begin{array}{c}0,14- \\
0,32\end{array}$ & $\begin{array}{c}0,25 \pm \\
0,0028 a\end{array}$ & 114 & $\begin{array}{c}0,11 \\
-0,30\end{array}$ & $\begin{array}{c}0,26 \pm \\
0,0023 a\end{array}$ & 105 & $\begin{array}{c}0,12 \\
-0,30\end{array}$ \\
\hline Female longevity & $9,06 \pm 0,65 a$ & 18 & 4-15 & $8,24 \pm 0,46 a$ & 25 & $5-12$ & $7.89 \pm 0,59 a$ & 19 & $3-19$ \\
\hline Male longevity & $9,00 \pm 0,72 a$ & 18 & $5-14$ & $7,84 \pm 0,50 a$ & 25 & $4-12$ & $7.63 \pm 0,58 a$ & 19 & $3-18$ \\
\hline Sex ratio $\overbrace{+}: \widehat{\jmath}$ & $0,9: 1 a$ & 122 & & $0,8: 1 a$ & 114 & & $0,8: 1 a$ & 105 & \\
\hline $\begin{array}{l}\text { Spermatophores } \\
\text { per female }\end{array}$ & $1,78 \pm 0,33 a$ & 18 & $0-5$ & $1,32 \pm 0,19 a$ & 25 & $0-4$ & $1,05 \pm 0,16 a$ & 19 & $0-3$ \\
\hline $\begin{array}{l}\text { Preoviposition } \\
\text { period }\end{array}$ & $3,25 \pm 0,39 a$ & 12 & $1-6$ & $5,13 \pm 0,35 b$ & 16 & $2-8$ & $\begin{array}{l}4,58 \pm \\
0,45 a b\end{array}$ & 12 & $3-8$ \\
\hline $\begin{array}{l}\text { Oviposition } \\
\text { period }\end{array}$ & $4,50 \pm 0,72 a$ & 12 & $1-8$ & $2,81 \pm 0,53 a$ & 16 & $1-8$ & $3,83 \pm 0,71 a$ & 12 & $1-8$ \\
\hline $\begin{array}{c}\text { Postoviposition } \\
\text { period }\end{array}$ & $1,58 \pm 0,65 a$ & 12 & $0-7$ & $1,00 \pm 0,27 a$ & 16 & $0-3$ & $1,50 \pm 0,42 a$ & 12 & $0-4$ \\
\hline Fecundity & $\begin{array}{c}416,69 \pm \\
110,27 a\end{array}$ & 16 & $0-1337$ & $\begin{array}{c}274,05 \pm \\
68,18 a\end{array}$ & 21 & 0-1015 & $\begin{array}{c}306,19 \pm \\
83,37 a\end{array}$ & 16 & $0-1145$ \\
\hline Fertility & $48,10 \pm 9,10 a$ & 12 & $0-86,37$ & $54,74 \pm 7,69 a$ & 16 & $0-100$ & $\begin{array}{l}55,36 \pm \\
10,33 a\end{array}$ & 12 & $0-100$ \\
\hline
\end{tabular}

Duration in days (mean \pm SE) of egg, larval (L1-L6), and pupal stages, pupal mass (g), female and male longevity (days), sex ratio (F:M), number of spermatophores per female, duration of preoviposition, oviposition and postoviposition periods (days), fecundity (number of eggs per female), and fertility (\%). Values followed by same letters within a row are not significantly different according to Kruskal-Wallis test $(P>0.05)$. 
and number of spermatophores per female $(\mathrm{H}=$ $17.83, P=<0.0001$ ). The low fecundity (an average of 103.4 eggs per female) and fertility (6.4\%) rates recorded for the hybrid crosses did not allow making backcrosses and interhybrids crosses between Tucumán and Salta populations. spermatophores per female, fecundity and fertility parameters showed higher values in parental crosses than in hybrid crosses. Such values pointed to the existence of postzygotic incompatibility. In this study, hybrid crosses resulted in 27 of 60 females (45\%) not carrying spermatophores in their reproductive tracts, which is a common and practical approach to quantify mating success (Table III and V). This analysis also revealed prezygotic incompatibility (Rhainds 2010).

\section{DISCUSSION}

This study compared biological, reproductive parameters and mating compatibility between C. includens populations from different geographically distance and from different hosts in Argentina. This study is the first report of mating compatibility among C. includens populations in Argentina.

The results of this study showed that under laboratory conditions, soybean looper populations from Salta collected in bean crop complete a single generation (from egg to adult) in approximately 35 days, longer than Santiago del Estero and Tucumán (31 and 32 days, respectively), collected in soybean crop. Similar results were reported by Combe \& Pérez (1978). A life cycle duration of 43 days was recorded by Barrionuevo et al. (2012) and 38-42 days by Moonga \& Davis (2016).

Egg stage duration was similar to those reported in previous studies (Canerday \& Arant 1967, Combe \& Peréz 1978, Navarro et al. 2009, Barrionuevo et al. 2012).

Chrysodeixis includens generally completes larval stage in six instars (Moscardi et al. 2012). However, $56 \%, 76 \%$ and $88 \%$ of the insects from Tucumán, Santiago del Estero and Salta, respectively, presented only six instars. The population from Salta had the highest percentage of individuals that molted for six instars. Shour \& Sparks (1981) observed a range from five to

Table II. Mean \pm SE (N) of parental crosses, hybrid crosses, backcrosses and interhybrid mating of Tucumán and Santiago del Estero Chrysodeixis includens populations.

\begin{tabular}{|c|c|c|c|c|}
\hline & Parental crosses* & Hybrid crosses & Backcrosses & Interhybrid mating \\
\hline $\begin{array}{c}\text { Spermatophores per } \\
\text { female }\end{array}$ & $1,51 \pm 0,18 \mathrm{a}(43)$ & $1,16 \pm 0,19 \mathrm{a}(43)$ & $1,29 \pm 0,07 \mathrm{a}(153)$ & $1,54 \pm 0,16 \mathrm{a}(63)$ \\
\hline $\begin{array}{c}\text { Preoviposition } \\
\text { period }\end{array}$ & $4,32 \pm 0,31 \mathrm{a}(28)$ & $4,80 \pm 0,45 \mathrm{ab}(20)$ & $5,02 \pm 0,13 \mathrm{~b}(99)$ & $4,57 \pm 0,15 \mathrm{a}(47)$ \\
\hline $\begin{array}{c}\text { Oviposition period } \\
\begin{array}{c}\text { Postoviposition } \\
\text { period }\end{array}\end{array}$ & $3,54 \pm 0,45 \mathrm{a}(28)$ & $4,25 \pm 0,73 \mathrm{a}(20)$ & $2,94 \pm 0,18 \mathrm{a}(99)$ & $3,79 \pm 0,29 \mathrm{a}(47)$ \\
\hline $\begin{array}{c}\text { Fecundity } \\
\text { Fertility }\end{array}$ & $335,73 \pm 61,61 \mathrm{~b}(37)$ & $189,61 \pm 46,05 \mathrm{a}(33)$ & $201,52 \pm 15,95 \mathrm{ab}(134)$ & $338,72 \pm 26,23 \mathrm{~b}(50)$ \\
\hline Fer (28) & $51,89 \pm 5,80 \mathrm{ab}(28)$ & $37,16 \pm 8,57 \mathrm{a}(20)$ & $59,62 \pm 2,98 \mathrm{~b}(97)$ & $72,40 \pm 3,81 \mathrm{c}(47)$ \\
\hline
\end{tabular}

* Is the average of the values of Tucumán and Santiago del Estero populations.

Values followed by same letters within a row are not significantly different according to Kruskal Wallis test $(P>0.05)$. 
seven instars larval, with a predominance of six instars when the larvae were fed on an artificial diet. The differences recorded in larval stage duration and number of instars may be due to the components of the artificial diet, and the rearing conditions (Barrionuevo et al. 2012). The duration of the overall larval stage from Tucumán and Santiago del Estero populations was in agreement with Moonga \& Davis (2016) and Canerday \& Arant (1967) who used soybean leaves and artificial diet to breed the larvae, respectively. The duration of the overall larval stage from Salta population was similar to that reported by Combe \& Pérez (1978) and Boldt et al. (1975). Besides, all the populations had shorter larval stage duration than reported by Barrionuevo et al. (2012) on artificial diet.

The pupal stage duration in Tucumán population, was similar to those recorded by Moonga \& Davis (2016), Navarro et al. (2009), Moscardi et al. (2012) and Canerday \& Arant (1967). Pupal stage from Salta and Santiago del Estero populations was similar to that reported by Barrionuevo et al. (2012). The pupal mass was similar to the one reported in other studies (Canerday \& Arant 1967, Jensen et al. 1974, Boldt et al. 1975). By contrast, Kidd \& Orr (2001) and Moonga \& Davis (2016) reported a lower pupal mass using soybean, cotton, cowpea (Vigna unguiculata L.) and sweet potato (Ipomoea batatas L.) leaves as larval diet.

Adult longevity for three populations was lower than reported by Combe \& Peréz (1978) and Canerday \& Arant (1967), but similar to those recorded by other authors (Jensen et al. 1974, Barrionuevo et al. 2012). In this study, it was found that females emerged before males, suggesting that $C$. includens is a protogyny species. No previous studies have reported this female behavior. The sex ratio found was of 0.8/0.9 F-1 M. Barrionuevo et al. (2012) and Combe \& Pérez (1978) reported a sex ratio with more females than males.

Number of spermatophores per female was generally 1 for the three populations, with a

Table III. Mean \pm SE (N) of parental crosses, hybrid crosses, backcrosses and interhybrid mating of Tucumán and Salta Chrysodeixis includens population.

\begin{tabular}{|c|c|c|c|c|}
\hline & Parental crosses* & Hybrid crosses & Backcrosses** & $\begin{array}{c}\text { Interhybrid } \\
\text { mating** }\end{array}$ \\
\hline $\begin{array}{c}\text { Spermatophores per } \\
\text { female }\end{array}$ & $1,41 \pm 0,19 \mathrm{a}(37)$ & $0,5 \pm 0,08 \mathrm{~b}(60)$ & - & - \\
\hline $\begin{array}{c}\text { Preoviposition } \\
\text { period }\end{array}$ & $4,04 \pm 0,33 \mathrm{a}(24)$ & $5,37 \pm 0,40 \mathrm{~b}(19)$ & - & - \\
\hline Oviposition period & $4,28 \pm 0,49 \mathrm{a}(24)$ & $3,00 \pm 0,62 \mathrm{a}(19)$ & - & - \\
\hline $\begin{array}{c}\text { Postoviposition } \\
\text { period }\end{array}$ & $1,48 \pm 0,37 \mathrm{a}(24)$ & $2,58 \pm 0,54 \mathrm{a}(19)$ & - & - \\
\hline Fecundity & $361,44 \pm 68,72 \mathrm{a}(32)$ & $103,41 \pm 41,54 \mathrm{~b}(27)$ & - & - \\
\hline Fertility & $51,73 \pm 6,78 \mathrm{a}(24)$ & $6,41 \pm 4,14 \mathrm{~b}(14)$ & - & - \\
\hline
\end{tabular}

* Is the average of the values of the Tucumán and Salta populations.

**The low values of spermatophores per female, fecundity and fertility prevented carrying out the blackcrosses and Hybrid. Values followed by same letters within a row are not significantly different according to Kruskal Wallis test with comparisons of pairs $(P>0.05)$. 
range from 1 to 5. This observation was similar to reported by Jensen et al. (1974).

The duration of preoviposition period from Tucumán and Salta populations was similar to those recorded by Canerday \& Arant (1967) and Combe \& Pérez (1978). The duration of this period for Santiago del Estero population was higher than those reported (Canerday \& Arant 1967, Combe \& Pérez 1978). The oviposition period was similar to that reported by Barrionuevo et al. (2012). No previous studies have examined C. includens postoviposition period.

Fecundity was similar to those reported by Barrionuevo et al. (2012) and Jensen et al. (1974); but it was lower than those reported by other authors (Combe \& Pérez 1978, Kidd \& Orr 2001). Total fertility for all populations, was higher than reported by Moonga \& Davis (2016) and lower than reported by Barrionuevo et al. (2012).

The results about mating compatibility between $C$. includens populations from Tucumán and Santiago del Estero) collected in soybean crop, did not show signs of geographical isolation. The presence of spermatophores in bursa copulatrix of females, and fecundity and fertility values, recorded in the different types of crosses, demonstrated successfully mating in both directions. This may account for the long-range migratory capacity of this species, whose presence has been widely documented in the American continent (Pogue 2005, Navarro et al. 2009). Palma et al. (2015) carried out the first molecular characterization of $C$. includens populations in soybean crops in Brazil and determined the existence a low but significant genetic differentiation among populations not related to geographical distance. The successful mating between $C$. includens populations from soybean crops presented in this study support the results reported by Palma et al (2015). The present study can contribute to the understanding of gene flow among $\mathrm{C}$. includens individuals from different provinces, a knowledge that is necessary to plan management programs aimed at offsetting resistance to Bt crops and insecticides (Grimi et al. 2018). Transgenic cotton and soybean crops that express Cry1Ac insecticidal proteins have been commercialized in Argentina since 1998 and 2012, respectively, and Chrysodeixis includens is one of the target pests of these technologies (Massoni et al. 2015). In 2017, Bt soybean was produced on 3.08 million hectares and Bt cotton on 250.000 hectares in Argentina. Currently the area cultivated with Bt crops is increasing rapidly and Argentina ranks third in planted biotech crops, with a total of 23.9 million hectares (ISAAA 2018). Furthermore, the soybeans that express a single insecticidal protein Cry1Ac, did not fully meet the high-dose concept for $\mathrm{C}$. includens, which is one of the most important parameters in IRM programs (Bernardi et al. 2012).

Mating compatibility between Tucumán and Salta populations collected in soybean and bean crops, respectively, showed lower values of fecundity (103.4 eggs per female) and fertility (6.4\%) parameters, spermatophores per female (0.5) and percentage mated female ( 41.9 and 48.3 $\%)$ in hybrid crosses than in parental crosses (Table IV). Also, these low values put off the possibility of making subsequent backcrosses and interhybrid mating of this study (Table $\mathrm{V}$ ). These results suggested the presence of a barrier of gene flow between $C$. includens populations from soybean and bean which may be based on the different nutrients each plant species (Pashley 1988, Murúa et al. 2008) or pest control strategies used in the fields that would affect the behavior of this species (Palma et al. 2015). Besides, in Argentina, bean production is located in the northwest region, with the Salta province covering $44 \%$ of total national bean production, which makes it the largest producer in the country (Ministerio de Agroindustria de 
Table IV. Detailed results of parental crosses, hybrid crosses, backcrosses and interhybrid mating of Tucumán (S) and Santiago del Estero (E) Chrysodeixis includens populations.

\begin{tabular}{|c|c|c|c|c|c|c|c|}
\hline Type of crosses & ㅇ & $0^{2}$ & $\mathbf{N}^{\circ}$ paired & $\begin{array}{l}\text { Mated } \\
\text { female }\end{array}$ & $\begin{array}{c}\text { Mated } \\
\%\end{array}$ & $\begin{array}{c}\text { Fecundity } \\
\text { mean } \pm \text { SE (N) }\end{array}$ & $\begin{array}{l}\text { Fertility } \\
\% \pm \text { SE (N) }\end{array}$ \\
\hline Parental crosses & S & $S$ & 18 & 16 & 88,9 & $\begin{array}{c}416,69 \pm 110,27 \\
(16)\end{array}$ & $48,10 \pm 9,10(12)$ \\
\hline Parental crosses & E & E & 25 & 21 & 84.0 & $\begin{array}{c}274,05 \pm 68,18 \\
(21)\end{array}$ & $54,74 \pm 7,69(16)$ \\
\hline Hybrid crosses & $\mathrm{S}$ & E & 21 & 15 & 71.4 & $\begin{array}{c}134,80 \pm 55,07 \\
(15)\end{array}$ & $39,42 \pm 14,32(7)$ \\
\hline Hybrid crosses & E & $\mathrm{S}$ & 22 & 18 & 81.8 & $\begin{array}{c}235,28 \pm 70,48 \\
(18)\end{array}$ & $35,94 \pm 11,1(13)$ \\
\hline Backcrosses & $\mathrm{S}$ & $\mathrm{F}_{1}(\mathrm{~S}+\mathrm{P} \times \mathrm{E} \widehat{O})$ & 14 & 13 & 92.9 & $\begin{array}{c}201,08 \pm 47,90 \\
(13)\end{array}$ & $41,27 \pm 10,74(10)$ \\
\hline Backcrosses & $\mathrm{E}$ & $\mathrm{F}_{1}\left(\mathrm{~S}+\mathrm{x} \times \mathrm{E}^{\widehat{\prime}}\right)$ & 18 & 17 & 94.4 & $\begin{array}{c}286,71 \pm 40,85 \\
(17)\end{array}$ & $72,66 \pm 6,66(14)$ \\
\hline Backcrosses & $\mathrm{S}$ & $\mathrm{F}_{1}\left(\mathrm{E}+\times \mathrm{SO}^{\hat{\imath}}\right)$ & 19 & 18 & 94.7 & $\begin{array}{c}244,11 \pm 44,25 \\
(18)\end{array}$ & $62,49 \pm 7,95(15)$ \\
\hline Backcrosses & E & $\mathrm{F}_{1}\left(\mathrm{E} P \times \mathrm{S} \mathrm{O}^{\hat{n}}\right)$ & 27 & 25 & 92.6 & $\begin{array}{c}205,00 \pm 47,52 \\
(25)\end{array}$ & $54,97 \pm 7,35(16)$ \\
\hline Backcrosses & $\mathrm{F}_{1}\left(\mathrm{~S} q \times \mathrm{E} \mathrm{O}^{-}\right)$ & S & 13 & 13 & 100 & $\begin{array}{c}164,31 \pm 38,04 \\
(13)\end{array}$ & $58,73 \pm 12,57(10)$ \\
\hline Backcrosses & $\mathrm{F}_{1}\left(\mathrm{~S} q \times \mathrm{E} \mathrm{O}^{-}\right)$ & E & 15 & 13 & 86.7 & $\begin{array}{c}147,77 \pm 55,31 \\
(13)\end{array}$ & $49,36 \pm 8,40$ \\
\hline Backcrosses & $F_{1}\left(E q \times S \delta^{\lambda}\right)$ & $\mathrm{S}$ & 20 & 15 & 75,0 & $\begin{array}{c}216,67 \pm 41,84 \\
(15)\end{array}$ & $64,81 \pm 8,14(11)$ \\
\hline Backcrosses & $F_{1}\left(E Q+S S^{\lambda}\right)$ & E & 27 & 20 & 74,1 & $134,5 \pm 32,17(20)$ & $64,70 \pm 5,67(13)$ \\
\hline $\begin{array}{l}\text { Interhybrids } \\
\text { mating }\end{array}$ & $\mathrm{F}_{1}\left(\mathrm{~S} P \times \mathrm{E} \mathrm{O}^{\lambda}\right)$ & 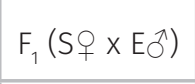 & 24 & 20 & 83.3 & $\begin{array}{l}246,40 \pm 27,50 \\
(20)\end{array}$ & $53,86 \pm 7,18(19)$ \\
\hline $\begin{array}{l}\text { Interhybrids } \\
\text { mating }\end{array}$ & $\mathrm{F}_{1}\left(\mathrm{~S} P \times \mathrm{E} \mathrm{O}^{-}\right)$ & $\mathrm{F}_{1}\left(\mathrm{E}+\mathrm{PSS}^{\lambda}\right)$ & 7 & 6 & 85.7 & $\begin{array}{c}488,17 \pm 48,69 \\
(6)\end{array}$ & $78,79 \pm 2,77(6)$ \\
\hline $\begin{array}{l}\text { Interhybrids } \\
\text { mating }\end{array}$ & $\mathrm{F}_{1}\left(\mathrm{E} q \times \mathrm{S} \mathrm{O}^{\hat{2}}\right)$ & $\mathrm{F}_{1}\left(\mathrm{~S} \rho \times \mathrm{E} \bigotimes^{\lambda}\right)$ & 8 & 5 & 62.5 & $\begin{array}{c}423,80 \pm 82,65 \\
(5)\end{array}$ & $83,26 \pm 6,85(5)$ \\
\hline $\begin{array}{l}\text { Interhybrids } \\
\text { mating }\end{array}$ & $\mathrm{F}_{1}\left(\mathrm{E} q \times \mathrm{S} \mathrm{O}^{\lambda}\right)$ & $\mathrm{F}_{1}\left(\mathrm{E} q \times \mathrm{S} \mathrm{O}^{\lambda}\right)$ & 24 & 19 & 79.2 & $\begin{array}{c}366,32 \pm 49,43 \\
(19)\end{array}$ & $87,68 \pm 2,20(17)$ \\
\hline
\end{tabular}

Argentina 2016). This concentration of bean plantations may be promoting physiological adaptations of this pest to the crop. However, additional research based on reproductive compatibility studies of $C$. includens populations from other crops, and the effect of management strategies will further deepen our understanding of the mating isolation found in the present study, and clarify the possible existence of host races. 
Table V. Detailed results of parental crosses, hybrid crosses, backcrosses and interhybrid mating of Tucumán (S) and Salta (B) Chrysodeixis includens populations.

\begin{tabular}{|l|c|c|c|c|c|c|c|}
\hline Type of crosses & + & O & $\mathbf{N}^{\circ}$ paired & $\begin{array}{c}\text { Mated } \\
\text { female }\end{array}$ & Mated \% & $\begin{array}{c}\text { Fecundity } \\
\text { mean } \pm \text { SE (N) }\end{array}$ & $\begin{array}{c}\text { Fertility } \\
\% \pm \text { SE (N) }\end{array}$ \\
\hline Parental crosses & S & S & 18 & 16 & 88,9 & $416,69 \pm 110,27(16)$ & $48,10 \pm 9,1(12)$ \\
\hline Parental crosses & B & B & 19 & 16 & 84,2 & $306,19 \pm 83,37(16)$ & $55,36 \pm 10,33(12)$ \\
\hline Hybrid crosses & S & B & 31 & 13 & 41.9 & $147,69 \pm 69,52(13)$ & $11,08 \pm 6,97(8)$ \\
\hline Hybrid crosses & B & S & 29 & 14 & 48.3 & $62,29 \pm 47,35(14)$ & $0,18 \pm 0,18(6)$ \\
\hline
\end{tabular}

\section{Acknowledgments}

This study is part of the first author's doctoral thesis. RAA is member of the Carrera del Investigador Científico y Tecnológico del CONICET. The authors thank Ings. Martín Luna and Marcelo Druetta (INTA-Quimili) for insects collection in Santiago del Estero province. Ing. Roxana Avila for excellent technical support and assistance in the collection of insects in Salta province and special thanks Ing. Javier A. Arrieta (EEAOC) for his support in all trials of this study. The authors also thank Ing. Miguel Morandini (EEAOC) for comments on statistic analysis and Ing. Eduardo Willink (EEAOC) and Lic. Adriana Manes for critical review of the earlier draft of the manuscript and valuable comments. This study was supported by the Agencia Nacional de Promoción Científica de Argentina (ANPCYT) through the Fondo Nacional de Ciencia y Tecnología (FONCYT), Ministerio de Ciencia, Tecnología e Innovación Productiva (MINCyT) (Grant PICTO 2016 EEAOC N 0112, Préstamo BID), Proyectos de Desarrollo Tecnológico y Social (PDTS N 302), EEAOC, and CONICET.

\section{REFERENCES}

ANGULO AO \& WEIGERT GTH. 1985. Estados inmaduros de lepidópteros Nóctuidos de Importancia Económica en Chile y Claves para du Determinación (Lepidoptera: Noctuidae) Soc Biol Concepción Publicación Especial 2: 151.

BALDIN ELL, LOURENÇÃO AL \& SCHLICK-SOUZA EC. 2014. Outbreaks of Chrysodeixis includens (Walker) (Lepidoptera: Noctuidae) in common bean and castor bean in São Paulo State, Brazil. Bragantia 73(4): 458-465.

BARRIONUEVO MJ, MURÚA MG, GOANE L, MEAGHER R. \& NAVARRO F. 2012. Life table studies of Rachiplusia nu (Guenée) and Chrysodeixis (= Pseudoplusia) includens
(Walker) (Lepidoptera: Noctuidae) on artificial diet. Fla Entomol 95(4): 944-951.

BARRIONUEVO MJ \& SAN BLAS G. 2015. Redescription of immature stages of the soybean looper (Lepidoptera: Noctuidae: Plusiinae). Can Entomol 148(3): 247-259.

BERNARDI O, MALVESTITI GS, DOURADO PM, OLIVEIRA WS, MARTINELLI S, BERGER GU, HEAD GP \& OMOTO C. 2012. Assessment of the high-dose concept and level of control provided by MON 87701× MON 89788 soybean against Anticarsia gemmatalis and Pseudoplusia includens (Lepidoptera: Noctuidae) in Brazil. Pest Manag Sci 68 (7): 1083-1091.

BICKFORD D, LOHMAN DJ, SODHI N, NG PKL, MEIER R, WINKER K, INGRAM KK \& DAS I. 2007. Cryptic species as a window on diversity and conservation. Trends Ecol Evol 22: 148-155.

BOLDT PE, BIEVER KD \& IGNOFFO CM. 1975. Lepidopteran pests of soybeans: consumption of soybean foliage and pods and development time. J Econ Entomol 68(4): 480-482.

CANERDAY TD \& ARANT FS. 1967. Biology of Pseudoplusia includens and notes on the biology of Trichoplusia ni, Rachiplusia nu, and Autographa biloba. J Econ Entomol 60(3): 870-871.

CARTER-WIENTJES CH, RUSSIN JS, BOETHEL DJ, GRIFFIN JL \& MCGAWLEY EC. 2004. Feeding and maturation by soybean looper (Lepidoptera: Noctuidae) larvae on soybean affected by weed, fungus, and nematode pests. J Econ Entomol 97: 14-20.

CASMUZ AS ET AL. 2014. Evaluación de diferentes alternativas para el control del complejo de plagas del cultivo de soja. p. 137-142 in Devani MR, Ledesma F and Sánchez JR (Eds). El cultivo de la soja en el noroeste argentino. Campaña 2013-2014. Publicación Especial Soja EEAOC N 50, Las Talitas, Tucumán, Argentina, EEAOC. Available online at http://www.eeaoc.org.ar/ 
publicaciones/categoria/16/461/10Plagas.html (last accessed 18 July 2017).

CASMUZ AS ET AL. 2015. Momento de aplicación de los insecticidas y su relación con el control ejercido sobre el complejo de orugas defoliadoras de la soja. p. 120-125 in Devani MR, Ledesma F and Sánchez JR (Eds). El cultivo de soja en el Noroeste Argentino campaña 2014/2015. Publicación Especial Soja EEAOC N 51, Las Talitas, Tucumán, Argentina, EEAOC. Available online at http:// www.eeaoc.org.ar/publicaciones/categoria/16/539/62Zoologia-621Defoliadoras.html (last accessed 18 July 2017).

COMBE IL \& PÉREZ GP. 1978. Biología del "Gusano Medidor" Pseudoplusia includens (Walk.) (Lep., Noctuidae). Rev Peruana de Entomol 21: 61-62.

DE LIMA VIANA D, NETTO JC, AGUIRRE-GIL OJ \& BUSOLI AC. 2014. Parâmetros biológicos da lagarta falsa-medideira em cultivares de algodoeiro com as proteínas Cry1Ac e Cry1F. Pesqui Agropecu Bras 49(7): 569-572.

DI RIENZO JA, CASANOVES F, BALZARINI MG, GONZALEZ L, TABLADA M \& ROBLEDO CW. 2008. InfoStat, versión 2016. Grupo InfoStat, FCA, Universidad Nacional de Córdoba, Argentina.

DREES BM \& RICE ME. 1985. The vertical beat sheet: a new device for sampling soybean insects. J Econ Entomol 78(6): 1507-1510.

DRÈS M \& MALLET J. 2002. Host races in plantfeeding insects and their importance in sympatric speciation. Philosophical Transactions of the Royal Society of London. Biol Sci 357(1420): 471-492.

EVENDEN ML, SPOHN BG, MOORE AJ, PREZIOSI RF \& HAYNES KF. 2002 Inheritance and evolution of male response to sex pheromone in Trichoplusia ni (Lepidoptera: Noctuidae). Chemoecology 12: 53-59.

FELLAND CM, PITRE HN, LUTTRELL RG \& HAMER JL. 1990. Resistance to pyrethroid insecticides in soybean looper (Lepidoptera: Noctuidae) in Mississippi. J Econ Entomol 83(1): 35-40.

FRANKLIN MT, RITLAND CE \& MYERS JH. 2010. Spatial and temporal changes in genetic structure of greenhouse and field populations of cabbage looper, Trichoplusia ni. Mol Ecol 19: 1122-1133.

GRIMI DA, PARODY B, RAMOS ML, MACHADO M, OCAMPO F, WILLSE A, MARTINELLI S \& HEAD G. 2018. Field-evolved resistance to Bt maize in sugarcane borer (Diatraea saccharalis) in Argentina. Pest Manag Sci 74(4): 905-913.

HERRERO MI, FOGLIATA SV, VERA A, CASMUZ A, GÓMEZ DS, CASTAGNARO AP, GASTAMINZA G \& MURÚA MG. 2017. Biological characterization and mating compatibility of Helicoverpa gelotopoeon (D.) (Lepidoptera: Noctuidae) populations from different regions in Argentina. Bull Entomol Res 108(1): 108-115.

HIGLEY LG \& BOETHEL DJ. 1994. Handbook of soybean insect pests. Entomol Soc Am 70-71.

ISAAA - INTERNATIONAL SERVICE FOR THE ACQUISITION OF AGRI-BIOTECH APPLICATIONS. 2018. Available online at http://www.isaaa.org/resources/publications/ briefs/54/executivesummary/default.asp (last accessed 10 September 2019).

JENSEN RL, NEWSOM LD \& GIBBENS J. 1974. The soybean looper: Effects of adult nutrition on oviposition, mating frequency, and longevity. J Econ Entomol 67(4): 467-470.

JOYCE AL, WHITE WH, NUESSLY GS, SOLIS MA, SCHEFFER SJ, LEWIS ML \& MEDINA RF. 2014. Geographic population structure of the sugarcane borer, Diatraea saccharalis (F.) (Lepidoptera: Crambidae), in the southern United States. PLOS ONE 9(10): e110036.

KIDD KA \& ORR DB. 2001. Comparative feeding and development of Pseudoplusia includens (Lepidoptera: Noctuidae) on kudzu and soybean foliage. Anna Entomol Soc Am 94(2): 219-225.

KRUSKAL WH \& WALLIS WA. 1952. Use of ranks on onecriterion variance analysis. J Am Stat Assoc 47: 583-621.

MASCARENHAS RN \& BOETHEL DJ. 2000. Development of diagnostic concentrations for insecticide resistance monitoring in soybean looper (Lepidoptera: Noctuidae) larvae using an artificial diet overlay bioassay. J Econ Entomol 93(3): 897-904.

MASCARENHAS RN, BOETHEL DJ, LEONARD BR, BOYD ML \& CLEMENS CG. 1998. Resistance monitoring to Bacillus thuringiensis insecticides for soybean loopers (Lepidoptera: Noctuidae) collected from soybean and transgenic Bt-cotton. J Econ Entomol 91(5): 1044-1050.

MASSONI F, SCHLIE G \& FRANA JE. 2015. Cultivo de soja Bt [RR2 PRO] y convencional [RR1] expuestos a poblaciones naturales de organismos plaga y depredadores. Publicación miscelánea INTA EEA Rafaela, 128 p.

MINISTERIO DE AGROINDUSTRIA DE ARGENTINA. 2016. https:// www.agroindustria.gob.ar/sitio/areas/ss_mercados_ agropecuarios/areas/regionales/_archivos/000030_ Informes/000040_ Legumbres/000009_ Producci\% C3\% B 3 n \% 20 Argentina $\% 20$ de \% 20 Legumbres\%20-\%202016.pdf (last accessed 28 June 2018). 
MOONGA MN \& DAVIS JA. 2016. Partial life history of Chrysodeixis includens (Lepidoptera: Noctuidae) on summer hosts. J Econ Entomol 109(4): 1713-1719.

MORRONE JJ. 2014. Biogeographical regionalisation of the Neotropical region. Zootaxa 3782(1): 1-110.

MOSCARDI F, BUENO AF, SOSA-GÓMEZ DR, ROGGIA S, HOFFMANN-CAMPO CB, POMARI AF, CORSO IC \& YANO SAC. 2012. Artrópodes que atacam as folhas da soja. Soja. Manejo integrado de insetos e outros artrópodes-praga. Brasília, DF: Embrapa 214-334.

MURÚA MG, VERA MT, ABRAHAM S, JUARÉZ ML, PRIETO S, HEAD GP \& WILLINK E. 2008. Fitness and mating compatibility of Spodoptera frugiperda (Lepidoptera: Noctuidae) populations from different host plant species and regions in Argentina. Ann Entomol Soc Am 101: 639-649.

MURÚA MG, VIRLA E \& DEFAGÓ V. 2003. Evaluación de cuatro dietas artificiales para la cría de Spodoptera frugiperda (Lepidoptera: Noctuidae) destinada a mantener poblaciones experimentales de himenópteros parasitoides. Bol San Veg Plagas 29: 43-51.

NAVARRO FR, SAINI ED \& LEIVA PD. 2009. Clave pictórica de polillas de interés agrícola, agrupadas por relación de semejanza. INTA EEA Pergamino Buenos Aires Argentina, $100 \mathrm{p}$.

OWEN LN, CATCHOT AL, MUSSER FR, GORE J, COOK DC \& JACKSON R. 2013. Susceptibility of Chrysodeixis includens (Lepidoptera: Noctuidae) to reduced-risk insecticides. Fla Entomol 96(2): 554-559.

PALMA J, MAEBE K, GUEDES JVC \& SMAGGHE G. 2015. Molecular variability and genetic structure of Chrysodeixis includens (Lepidoptera: Noctuidae), an important soybean defoliator in Brazil. PLoS ONE 10(3): e0121260.

PASHLEY DP. 1988. Quantitative genetics, development and physiological adaptation in host strains of fall armyworm. Evolution 42: 93D102.

PÉREZ CONTRERAS T. 1999. La especialización en los insectos fitófagos: Una regla más que una excepción. Boletín S.E.A 26: 759-776.

POGUE MG. 2005. The Plusiinae (Lepidoptera: Noctuidae) of Great Smoky Mountains National Park. Zootaxa 1032(1): $1-28$.

RHAINDS M. 2010. Female mating failures in insects. Entomol Exp Appl 136: 211-226.

RULL J, ABRAHAM S, KOVALESKI A, SEGURA DF, ISLAM A, WORNOAYPORN V, DAMMALAGE T, SANTO TOMAS U \& VERA MT. 2012. Random mating and reproductive compatibility among Argentinean and southern Brazilian populations of Anastrepha fraterculus (Diptera: Tephritidae). Bull Entomol Res 102: 435-443.

SHOUR MH \& SPARKS TC. 1981. Biology of the Soybean Looper, Pseudoplusia includens: Characterization of Last-Stage Larvae. Ann Entomol Soc Am 74(6): 531-535.

SPECHT A, DE PAULA-MORAES SV \& SOSA-GÓMEZ DR. 2015. Host plants of Chrysodeixis includens (Walker) (Lepidoptera, Noctuidae, Plusiinae). Rev Bras Entomol 59(4): 343-345.

YANO SA, SPECHT A, MOSCARDI F, CARVALHO RA, DOURADO PM, MARTINELLI S, HEAD GP \& SOSA-GÓMEZ DR. 2015. High susceptibility and low resistance allele frequency of Chrysodeixis includens (Lepidoptera: Noctuidae) field populations to Cry1Ac in Brazil. Pest Manag Sci 72(8): 1578-1584.

ZHU JW, CHASTAIN BB, SPOHN BG \& HAYNES KF. 1997. Assortative mating in two pheromone strains of the cabbage looper moth, Trichoplusia ni. J Insect Behav 10: 805-817.

\section{How to cite}

DAMI LC, HERRERO MI, CASMUZ AS, ALZOGARAY RA \& GASTAMINZA GA. 2021. Fitness and mating compatibility of Chrysodeixis includens (W.) (Lepidoptera: Noctuidae) populations collected in different provinces and crops in Argentina. An Acad Bras Cienc 93: e20190523. DOI 10.1590/0001-3765202120190523.

Manuscript received on May 06, 2019;

accepted for publication on September 24, 2019

\section{LUCIANA C. DAMI ${ }^{1}$}

https://orcid.org/0000-0001-7665-1393

\section{MARÍA INÉS HERRERO'}

https://orcid.org/0000-0001-9924-1661

\section{AUGUSTO S. CASMUZ}

https://orcid.org/0000-0002-8390-5758

RAÚL A. ALZOGARAY

https://orcid.org/0000-0001-5816-7442

\section{GERARDO A. GASTAMINZA ${ }^{3}$}

https://orcid.org/0000-0003-1316-1834 
${ }^{1}$ Instituto de Tecnología Agroindustrial del Noroeste Argentino/ITANOA-CONICET, William Cross 3150,

4101, Las Talitas, Tucumán, Argentina

${ }^{2}$ Centro de Investigaciones de Plagas e Insecticidas, Instituto de Investigación e Ingeniería Ambiental, Universidad Nacional de San Martín/UNIDEF-CITEDEF-CONICET-CIPEIN, Juan Bautista de La Salle 4397, Villa Martelli, Buenos Aires, Argentina

${ }^{3}$ Estación Experimental Agroindustrial Obispo Colombres/

EEAOC, William Cross 3150, 4101, Las Talitas, Tucumán, Argentina

Correspondence to: Luciana Cecilia Dami

E-mail:lu.dami@hotmail.com

\section{Author contributions}

Luciana Cecilia Dami: design and test execution, data collection, statistical analysis, manuscript writing and corrections; María Inés Herrero: collaboration in test execution, data collection and statistical analysis; Augusto Sebastián Casmuz: supplier of biological material for testing; Raúl Adolfo Alzogaray: collaboration in writing the manuscript; Gerardo Alfredo Gastaminza: general input supplier.

\section{(cc) BY}

